\title{
皮膚表皮が持つバリア構造と機能からみたアレルギー疾患治療戦略
}

\author{
久保亮治
}

\section{Structural and Immunological Barriers of the Skin as Potential Therapeutic Targets}

\author{
Akiharu Kubo \\ Department of Dermatology, Keio University School of Medicine; 35 Shinanomachi, \\ Shinjuku-ku, Tokyo 160-8582, Japan.
}

(Received January 9, 2014)

\begin{abstract}
Skin is the structure that covers our body and protects it from not only the entry of pathogens or allergens but also from the leakage of water, solutes or nutrients. These outside-in and inside-out skin barrier functions are dependent on the epidermis, a stratified epithelial cellular sheet. While mucus covers the epidermis in fish and amphibian tadpoles, terminally differentiated cornified cellular sheets called stratum corneum (SC) constitute the outermost epidermal barrier in amphibian adults, reptiles, birds and mammals. Beneath the mucus or SC, apical paracellular spaces of epidermal cells are sealed with tight junctions (TJs) that limit paracellular leakage of water and electrolytes to maintain fluid homeostasis. We applied time-of-flight secondary-ion-mass-spectrometry (TOF-SIMS) imaging technology to analyze the SC in skin sections, and found that the SC consisting of three layers of distinct functional properties. Under the barriers of the SC and TJ, antigen-presenting dendritic cells called Langerhans cells (LCs) distribute within the epidermis. LCs elongate their dendrites to penetrate through epidermal TJs upon activation and uptake antigens from extra-TJ environment. During antigen uptake, new TJs are formed between keratinocytes and LC dendrites to maintain the integrity of epidermal TJ barriers. To understand the epidermal barrier system and its deficiency observed in human skin diseases, we need to re-evaluate human epidermal barrier as a composite barrier consisting of SC and TJs and to investigate the molecular mechanism and immunological consequences of the extra-TJ antigen uptake activity of LCs.
\end{abstract}

Key words_— skin barrier; atopic dermatitis; tight junction; stratum corneum; Langerhans cell

\section{はじめに}

角質構成タンパクフィラグリンの変異が, アト ピー性皮膚炎の発症要因として注目されている. フ イラグリンタンパク自体の減少と, その分解産物で ある天然保湿因子の減少により皮膚の角質バリア障 害が起こり，その結果アレルゲンが皮膚を通して体 内に侵入し易くなり，経皮的な抗原暴露が慢性的に 起こることで感作が成立し易くなり，遂にはアト ピー性皮膚炎発症に至るという仮説である. ${ }^{1,2)}$ しか し，角質のバリア機能はどのような性質のもので, それがどのように障害されるのか? 角質バリアを 超えて侵入した抗原はどのように免疫系に捉えられ るのか？についてはまだまだ不明な点が多い.わ

The author declares no conflict of interest.

慶應義塾大学医学部皮膚科（T160-8582 東京都新宿区 信濃町 35)

e-mail: akiharu@a5.keio.jp

本総説は, 日本薬学会第 133 年会シンポジウム S28202 で発表した内容を中心に記述したものである。
れわれは，質量分析顕微鏡技術を用いた角質バリア 構造の新しい解析手法を開発するとともに，角質バ リアの内側においてどのような外来抗原の取得機構 が働いているのか，その分子メカ二ズムの解析を行 っている.

皮膚が持つ 2 つのバリア：角質バリアとタイトジ ヤンクションバリア

表皮の最表面の角質層は，角化脱核した角質細胞 (corneocyte）とその細胞間を埋める角質細胞間脂 質によって構成されるバリア構造である。陸上の空 気環境に生きる春椎動物はすべて, 全身を覆う角質 層を持っている，角質層は空気環境と液性環境の間 を隔てるバリアであり，角質の内側の細胞を乾燥や 外力による障害から守っている. 角質層の内側の顆 粒層は, 非常に扁平化したケラチノサイトが複数積 み重なってできた層である。顆粒層の細胞を表面か ら順に SG1, SG2, SG3 細胞とそれぞれ名付けると, $\mathrm{SG} 2$ 細胞の細胞間にのみタイトジャンクション 


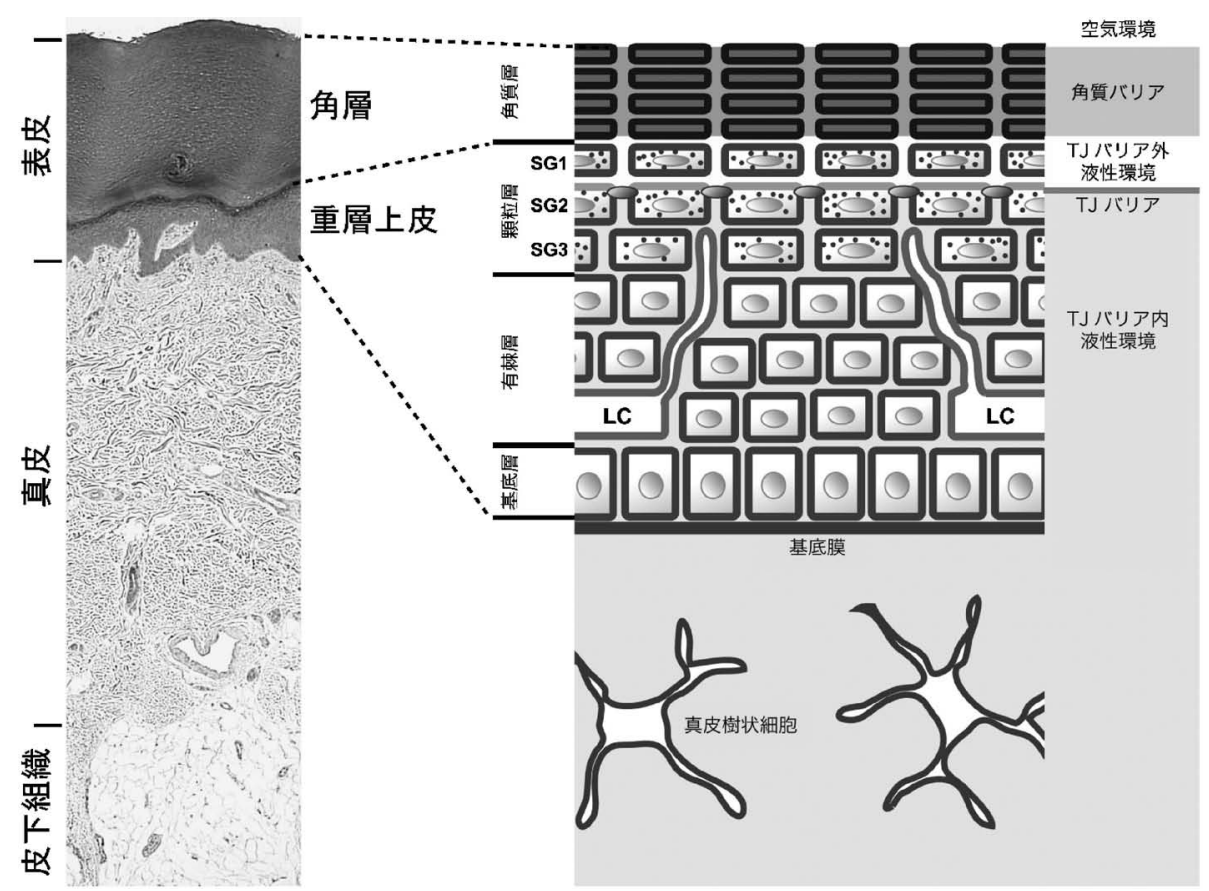

Fig. 1. Schematic Drawing of the Structure of the Epidermis ${ }^{6}$

（tight junction; TJ）が存在して細胞間を通る物質 移動を制限するバリアを形成している. ${ }^{3-5)}$ すなわ ち，われわれの表皮には角質とタイトジャンクショ ンという 2 つの物理的なバリア構造が存在する。顆 粒層の下の有棘層は，デスモソームの発達したケラ チノサイトが重層する層であり，ランゲルハンス細 胞と呼ばれる表皮内樹状細胞がこの有棘層に散在し ている (Fig. 1).

\section{質量分析顕微鏡による角層構造の可視化}

近年，質量分析の技術が進み，顕微鏡亡質量分析 の手法を組み合わせた質量分析顕微鏡が登場し，生 体観察に応用されつつある。質量分析顕微鏡の強み は，プローブを用いる必要がないため，物質そのも のの分布を直接観察できることと，一度の観察で様 々な物質の分布を同時に解析・可視化できることで ある，具体的には，サンプルの XY 座標上の各点を レーザーやイオンガンにて撃ち，そこからあらわれ た物質をすべて質量分析にて解析する，ということ を XY 上のすべての点について繰り返し行う．得ら れたデー夕を統合すると，逆にある質量を持つ物質 がXY 空間上でどのように分布していたか，をそれ ぞれの質量ピーク毎に画像化することができる. matrix assisted laser desorption/ionization-mass spectrometry（MALDI-MS，マトリックス支援レーザー
脱離イオン化質量分析）を用いた観察手法は，質量 分解能には優れるが，解像度が 50-100 $\mu \mathrm{m}$ と粗い ため，厚さが 30-50 $\mu \mathrm{m}$ 程度である角質層の解析に は適さない（得られる画像の 1 ピクセルの直径が角 層の厚さと同じぐらいになってしまう)。一方, time-of-flight secondary ion mass spectrometry (TOFSIMS，飛行時間型二次イオン質量分析）を用いた 観察手法は，MALDI-MS に比べて質量分解能には 劣るが， $1 \mu \mathrm{m}$ 以下の解像度を誇る（すなわち角層 の内部構造の可視化が可能である). ${ }^{7,8)}$ TOF-SIMS はこれまで主に半導体など無機物質の表面分析に用 いられてきた技術であり，生物試料への応用は始ま つたばかりである。われわれは TOF-SIMS による 質量分析顕微鏡技術を角質のバリア構造・機能の可 視化に応用した. ${ }^{9)}$

まず，TOF-SIMS により観察するのに適した皮 膚サンプルの作製方法，観察手法の最適化を行っ

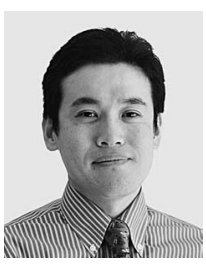

久保亮治
慶應義塾大学医学部皮膚科学教室 講 師。皮膚科専門医/臨床遺伝専門医。皮 膚が持つバリア機構の統合的な解析を 行うとともに，臨床家として様々な遺 伝性皮膚疾患と向き合い,「ベンチから 臨床へ」を目指して，迅速な診断方法 の開発，新しい治療方法の開発を行う ベく奮闘中である. 
た.クライオスタットにて作製したマウス尻尾皮膚 切片を， $-25^{\circ} \mathrm{C}$ の状態のままカバーガラス上に貼 り付けた導電性カーボンテープ上に貼り付け, クラ イオスタット内にてフリーズドライすることで，一 度も凍結融解させることなく TOF-SIMS にて観察 可能な切片を作製した．本方法にて作製した切片を TOF-SIMS 質量分析顕微鏡（PHI-TRIFT V，アル バックファイ株式会社）を用いて観察した。マウス の尻尾断面の低倍での観察では，細胞密度の濃い領 域（筋肉や表皮）はカリウム high，ナトリウム lowな 領域として観察された。一方，細胞密度の薄い領域 (結合織) はカリウム low，ナトリウム highな領域とし て観察された。これは, 細胞が常に ATP 依存性に カリウムを取り込みナトリウムを排出しているため であると考えられた。皮膚を高倍率にて観察したと ころ, カリウム low, ナトリウム highな領域として角 質層を，カリウム high, ナトリウム lowな領域として 生細胞層を，それぞれ観察することに成功した。ケ ラチノサイトが角化に伴って ATP 依存性のカリウ ムとナトリウムの交換を停止するために，生きた細 胞はカリウムに富む一方，角質細胞はナトリウムに 富むものと考えられた。 また，角層はセラミドの分 解産物を多く含んでいた。

質量分析顕微鏡による天然保湿因子成分の可視化

次に，われわれは天然保湿因子の角層内分布の可 視化に挑んだ。 天然保湿因子はフィラグリンの分解 産物であるため，フィラグリン欠損マウス ${ }^{10)}$ の皮膚 では著減していると考えられた。そこで野生型マウ スとフィラグリン欠損マウスの皮膚切片をそれぞれ TOF-SIMS にて観察し，フィラグリン欠損マウス にて減少しているピークを探したところ，質量電荷 比 $(m / z)=175.1$ のピークがフィラグリン欠損マウ ス皮膚にて著減していること，このピークを示す分 子が角質に特異的に存在していることを発見した. このピークは $m / z$ の值からフリーのアルギニン分 子と考えられた。TOF-SIMS にて精製アルギニン 標品を測定したところ，全く同じ $m / z=175.1$ の単 一のピークを観察した．以上から， $m / z=175.1$ の ピークはフィラグリンの分解産物であるアルギニン 分子を特異的に検出していると結論づけた。これ は，角層内における天然保湿因子の分布を可視化し た，世界で初めての成果である．興味深いことに， アルギニンは角質の中層に集積していた。一方，角
質の上層ではアルギニン濃度が低下する一方で，力 リウムが増加していた．角質の下層ではアルギニ ン，カリウムともに低濃度であった．以上より，角 質層は，カリウム high，アルギニンlowな上層，カリ ウ $厶^{\text {low }}$ アルギニン highな中層, カリウム ア $^{\text {low }}$, アル ギニンlowな下層，の3つの層に分けられることが 明らかとなった。非常に興味深いことに，これらの 3 層それぞれの境目は非常に明瞭であり，角質は顆 粒層から生成されてから，垢となって脱落していく までに，大きく 2 回，その性質を変化させると考え られた。

過去の cryoelectron microscopy による検討では, 角質の中層に水を含み易い層が存在することが示唆 されている. ${ }^{11)}$ また，フィラグリンの免疫電子顕微 鏡観察では，角層の最内層の数層でフィラグリンの 免疫シグナルが観察されるが，ある層で突然にフィ ラグリンの免疫シグナルがほぼ消失することが示さ れている. ${ }^{12)}$ 以上から，角質細胞は，既に mRNA の転写もタンパク質の翻訳も行われていない「死ん だ」組織であるにもかかわらず，厳密にその分化が 制御されており，角質下層から中層に変化する際 に，フィラグリンの分解が一気に進行してアミノ酸 にまで分解されることで，アルギニンのシグナルが 角質中層で出現すると考えられた。すなわち角質中 層は，天然保湿因子を多く含み，角質内の水分維持 機能を担っている層であると考えられた.

\section{質量分析顕微鏡による角層バリア解析}

次にわれわれは，重クロム酸カリウム・フルオロ セイン水溶液を用いた浸透実験を行い，重クロム酸 カリウムに含まれる六価クロムとフルオロセインの 角層内分布を TOF-SIMS を用いて可視化した。 六 価クロムとフルオロセインはともに，角質上層には 容易に浸透するが，角質中層には浸透しなかった。 また，カリウムも角質中層には浸透しなかった，以 上より，角質中層は天然保湿因子を多く含み，角層 内水分を保持する層として働くとともに，外から内 への物質浸透に対するバリアとしても働いていると 考えられた。一方，角質上層は様々な低分子が容易 に出入りするスポンジのような構造をとつているこ とが示唆された．次に，塩化クロム水溶液を用いた 浸透実験を行い，塩化クロムに含まれる三価クロム の角層内分布を TOF-SIMS を用いて可視化した. 六価クロムと比べて三価クロムは，様々なタンパク 


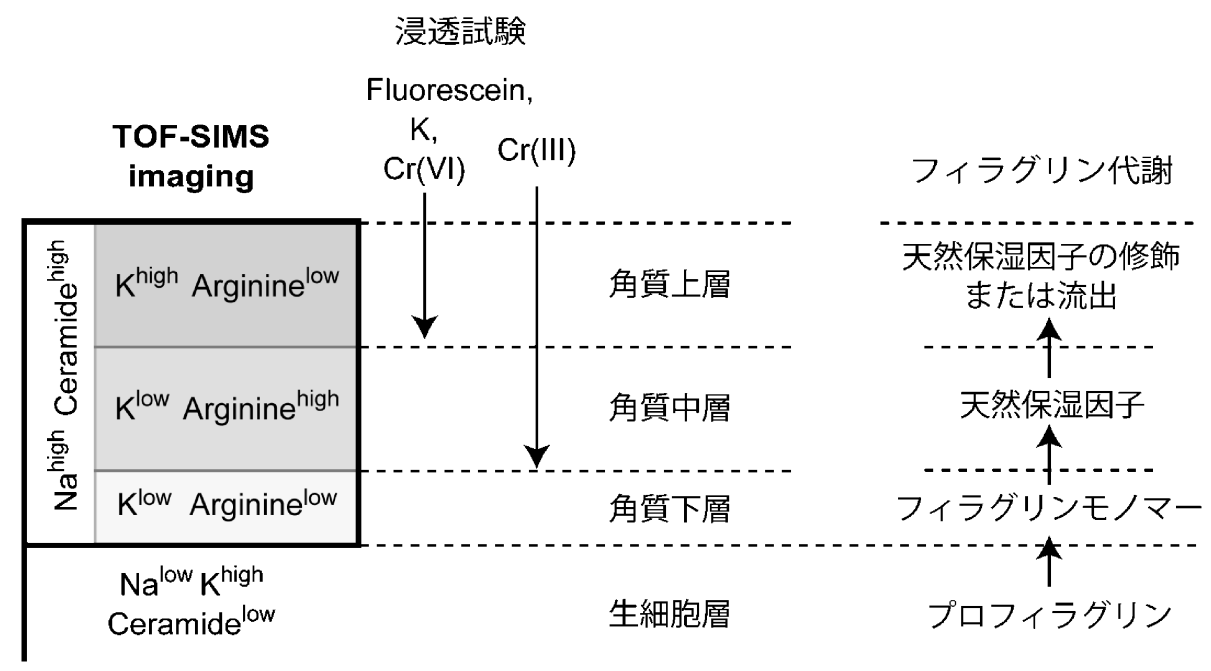

Fig. 2. Schematic Drawing of the Stratum Corneum Barrier ${ }^{9)}$

The stratum corneum consists of three layers with distinct functional properties.

やアミノ酸と複合体を作る反応性の高い物質である ことがわかっている. ${ }^{13)}$ 塩化クロム水溶液に 45 分 間浸したマウス尻尾の皮膚を観察したところ，三価 クロムが角質中層にまで浸透しており，角質中層に 存在するはずのアルギニンのシグナルが消失してい た。また，角質上層のカリウム，角質上層・中層の ナトリウムも同様に消失していた。一方，角質下層 のナトリウムは保持されていた，以上より，角質下 層も外部からの物質浸透に対するバリアとして働く こと，角質中層と角質下層のバリアの性能が異なる こと，が明らかとなった（Fig. 2).

角質バリア・TJ バリアと皮膚の免疫機構との係 わり

皮膚表皮には，自然免疫のシステムと獲得免疫の システムが存在し，角質と $\mathrm{TJ}$ という 2 つの物理的 バリアと協調して，外界からの侵入者に対して生体 を多重に守るバリアシステムを形成している。で は，皮膚のバリア機能が障害されたときに，免疫機 構はごのように反応するのか？ここでは，獲得免 疫のシステムに焦点を絞って解説する.

皮膚に存在する抗原取得細胞は，表皮内に存在す るランゲルハンス細胞と，真皮に存在する真皮樹状 細胞の 2 種類に大きく分けられる. 真皮樹状細胞に は langerin 陽性のものと陰性のものの, 少なくとも 2 つの population が存在することが明らかとなって

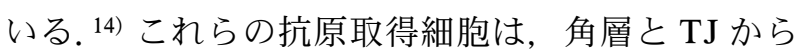
なる皮膚表皮のバリアの内側に存在しており，バリ アを破って侵入してきた抗原を捕捉し，最終的にリ
ンパ管を通って所属リンパ節に移動して，リンパ節 で $\mathrm{T}$ 細胞に対して抗原提示を行うと考えられてい る. 真皮内に存在し，真皮にまで侵入してきた抗原 を捉えると考えられる真皮樹状細胞に対して，ラン ゲルハンス細胞はより外界に近い表皮内に存在する 樹状細胞である.

ランゲルハンス細胞と TJ バリアの協調による外

\section{来抗原取り込み機構}

ランゲルハンス細胞は表皮 $\mathrm{TJ}$ バリアの内側の表 皮内に通常は存在しているが，活性化すると表皮 TJ バリアを超えて角質層直下にまで樹状突起を延 長し，TJバリアの外側で樹状突起の先端から抗原 取得を行う。また，このとき，ランゲルハンス細胞 は隣り合うケラチノサイトとの間に新たな TJ バリ アを構築することで，表皮の $\mathrm{TJ}$ バリアを保ったま ま TJ バリアの外側に樹状突起を伸ばしている。す なわち，角質層を通過して TJ バリアのすぐ外側ま で侵入した抗原（特に TJ バリアを通過できないよ うなサイズの大きいタンパク性抗原）は，表皮 $\mathrm{TJ}$ バリアにより生体内への侵入を防がれる一方，活性 化したランゲルハンス細胞により TJ バリアの外側 で抗原取得されていると考えられる (Fig. 3). ${ }^{4)}$ マ ウスを用いた実験により，ブドウ球菌が産生する表 皮剥脱毒素（ブドウ球菌性熱傷様皮膚症候群の原因 となる）をランゲルハンス細胞が TJ バリアの外側 で捉えることにより，Th2 の免疫が成立することが 示された. ${ }^{15)}$ 免疫が成立したマウスでは，表皮剥脱 毒素の腹腔注射によって誘導される全身性の水疮形 


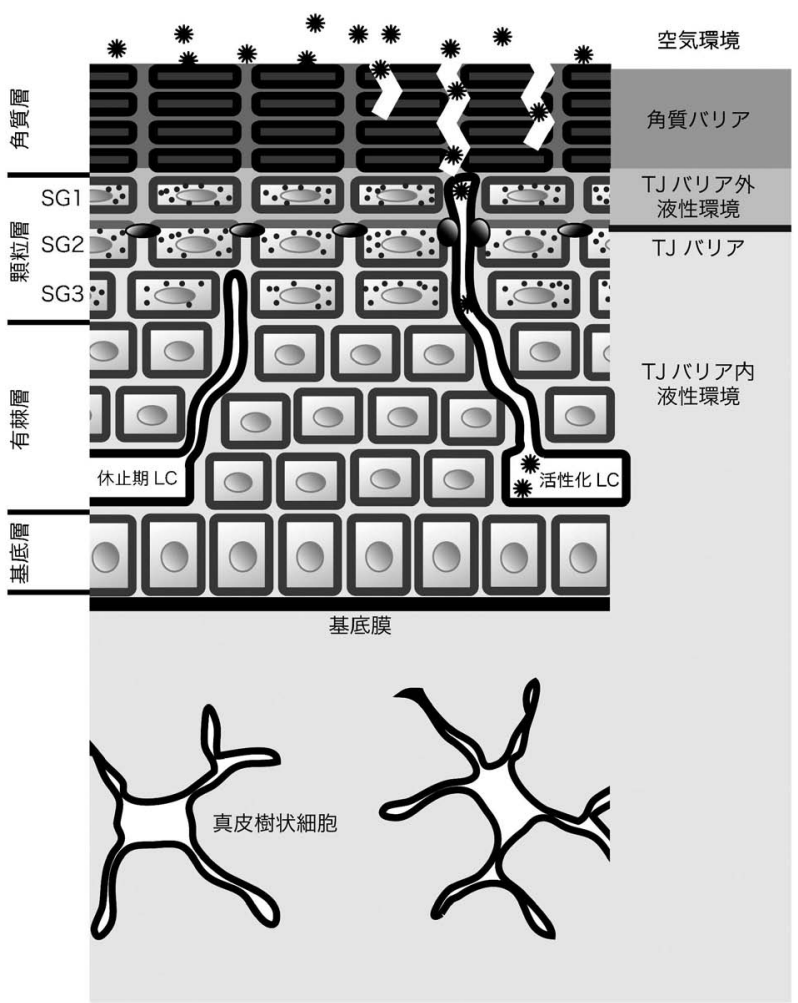

Fig. 3. Schematic Drawing of the Interaction between the Epidermal Tight Junction Barrier and Langerhans Cells

Activated Langerhans cells elongate their dendrites to penetrate through the epidermal tight junction barrier and take up antigens from the outside tight junction barrier.

成が抑制されており，TJバリアの外側からランゲ ルハンス細胞が抗原取得を行うことによって，（ま だ体内に侵入してきていない毒素をあらかじめ抗原 取得し免疫を成立させておく）予防的な免疫が成立 し得ることが示された. ${ }^{15)}$ ランゲルハンス細胞の本 機能が，アレルギー感作にどのように係わるのか, 今後の研究が注目される。一方， TJ バリアを通り 抜けられる抗原（例えばハプテンのような低分子） では, ランゲルハンス細胞以外の真皮樹状細胞も抗 原取得に係わる可能性が考えられる。これまでの経 皮感作の研究のほとんどは，表皮のバリア構造を無 視して真皮内に抗原を注射しており，今後，皮膚の バリア機能と抗原感作機構を考え合わせて，これま での経皮免疫の研究を見直していく必要があると考 えられた。

\section{まとめ}

以上のように，皮膚の最表層には，これまで考え られてきたよりもずっと複雑かつエレガントなバリ ア機構が備わっている。これらのバリア機構の破綻
がアトピー性疾患の発症に深く係わつていると考え られる. 皮膚バリア機構と抗原感作機構を解明して いくことで，アトピ一性疾患の予防・治療を目標と した新たな創薬ターゲットが生まれることが期待さ れる。

\section{REFERENCES}

1) Brown S. J., McLean W. H. I., J. Invest. Dermatol., 132, 751-762 (2012).

2) Kubo A., Nagao K., Amagai M., J. Clin. Invest., 122, 440-447 (2012).

3) Furuse M., Hata M., Furuse K., Yoshida Y., Haratake A., Sugitani Y., Noda T., Kubo A., Tsukita S., J. Cell Biol., 156, 1099-1111 (2002).

4) Kubo A., Nagao K., Yokouchi M., Sasaki H., Amagai M., J. Exp. Med., 206, 2937-2946 (2009).

5) Yoshida K., Yokouchi M., Nagao K., Ishii K., Amagai M., Kubo A., J. Dermatol. Sci., 71, 89-99 (2013).

6) Kubo A., Amagai M., Experimental Medicine, 29, 1634-1640 (2011).

7) Chaurand P., Cornett D. S., Caprioli R. M., Curr. Opin. Biotechnol., 17, 431-436 (2006) .

8) Touboul D., Kollmer F., Niehuis E., Brunelle A., Laprévote O., J. Am. Soc. Mass Spectrom., 16, 1608-1618 (2005).

9) Kubo A., Ishizaki I., Kubo A., Kawasaki H., Nagao K., Ohashi Y., Amagai M., Sci. Rep., 3, 1-11 (2013).

10) Kawasaki H., Nagao K., Kubo A., Hata T., Shimizu A., Mizuno H., Yamada T., Amagai M., J. Allergy Clin. Immunol., 129, 15381546.e6 (2012).

11) Bouwstra J. A., de Graaff A., Gooris G. S., Nijsse J., Wiechers J. W., van Aelst A. C., J. Invest. Dermatol., 120, 750-758 (2003).

12) Manabe M., Sanchez M., Sun T. T., Dale B. A., Differentiation, 48, 43-50 (1991).

13) Samitz M. H., Katz S., J. Invest. Dermatol., 43, 35-42 (1964).

14) Merad M., Ginhoux F., Collin M., Nat. Rev. Immunol., 8, 935-947 (2008).

15) Ouchi T., Kubo A., Yokouchi M., Adachi T., Kobayashi T., Kitashima D., Fujii H., Clausen B., Koyasu S., Amagai M., Nagao K., $J$. Exp. Med., 208, 2607-2613 (2011). 